\title{
Analysis of the effects of hospitalization on fine hand functions compared to gross grip in patients with rheumatoid arthritis
}

\author{
Romatoid artritli hastalarda hospitalizasyonun ince el fonksiyonlarına etkilerinin incelenmesi \\ ve kavramaya etkileriyle karşılaştırılması
}

Zeynep Tuna ${ }^{1}$, Deran Oskay ${ }^{1}$, Derya Onbulak ${ }^{2}$, Rıdvan Mercan ${ }^{3}$

\begin{abstract}
Objective: Hospitalization process causes a variety of physical problems. The decrease of hand use in daily life during hospitalization brings hand dysfunction to mind in inpatients. The aim of this study is to compare the hand functions of hospitalized patients with Rheumatoid Arthritis (RA) to outpatients in detail.
\end{abstract}

Methods: Grip and pinch strengths of both hospitalized patients in rheumatology service and outpatients on the routine control day were measured. In addition, 9-Hole Peg Test was performed and the disability level was determined by the Turkish version of Michigan Hand Outcomes Questionnaire (MHOQ).

Results: While grip strength and $\mathrm{MHOQ}$ scores were similar $(p>0.05)$ in both groups, all three pinch strengths (lateral, bipod, tripod) and 9HPT scores were lower $(p<0.05)$ in hospitalized patients.

Conclusion: Consequently, besides disease activity, hospitalization process also impairs fine hand functions in rheumatological patients. Evaluation of fine hand functions and appropriate rehabilitative interventions may prevent further disability in hospitalized patients. J Clin Exp Invest 2015; 6 (3): 228-232

Key words: Rheumatoid arthritis, rheumatoid hand, hand functions, dexterity, hospitalization

\section{INTRODUCTION}

Rheumatoid Arthritis (RA) is a systemic disease characterized by chronic inflammation that often affects small joints of the hand. Patients with RA receive treatment frequently as inpatient due to their complaints during inflammation periods.

\section{ÖZET}

Amaç: Hospitalizasyon süreci birçok fiziksel probleme yol açmaktadır. Hospitalizasyon sırasında elin günlük yaşamda kullanımının azalması, yatan hastalarda el disfonksiyonunu akla getirmektedir. Bu çalışmanın amacı, yatan Romatoid Artritli hastaların el fonksiyonlarının, dış hastalarla detaylı olarak karşılaştırılmasıdır.

Yöntemler: Yatan hastaların romatoloji servisinde ve dış hastaların rutin kontrol günlerinde kavrama ve çimdikleyici kuvvetleri ölçüldü. Ayrıca, hastalara 9 Delikli Peg Test (9DPT) yapıldı ve özür düzeyleri Michigan El Sonuçları Anketi Türkçe versiyonu (MESA-T) ile belirlendi.

Bulgular: Grupların kavrama ve MESA-T skorları benzer bulunurken ( $p>0,05)$; hospitalize hastaların her üç çimdikleyici (lateral, bipod, tripod) kuvvetleri daha düşük ve 9DPT skorları daha kötü bulunmuştur $(p<0,05)$.

Sonuç: Sonuç olarak, hastalık aktivitesinin yanı sıra, hospitalizasyon süreci de romatolojik hastalarda ince el fonksiyonlarını kötüleştirmektedir. İnce el fonksiyonlarının değerlendirilmesi ve buna uygun rehabilitasyon programlarının verilmesi, hospitalize hastalarda daha fazla özrü engelleyebilir.

Anahtar kelimeler: Romatoid artrit, romatoid el, el fonksiyonları, el becerisi, hospitalizasyon

Hospitalization results in various side effects, predominantly in deterioration of physical functions. Deterioration in physical functions causes dependency on others. Among the underlying mechanism of functional deterioration observed during hospitalization are such factors as immobilization, multiple drug use, and social or medical isolation [1]. De-

\footnotetext{
${ }^{1}$ Gazi University Faculty of Health Sciences Department of Physiotherapy and Rehabilitation, Ankara, Turkey

${ }^{2}$ Özel Eylül Rehabilitation Center, Eskişehir, Turkey

${ }^{3}$ Antakya State Hospital Department of Rheumatology, Antakya, Turkey

Correspondence: Zeynep Tuna,

Gazi University Faculty of Health Sciences Department of Physiotherapy \& Rehabilitation, Ankara, Turkey

Email: zeyneptuna6@yahoo.com

Received: 29.06.2015, Accepted: 24.08.2015

Copyright (C) JCEI / Journal of Clinical and Experimental Investigations 2015, All rights reserved
} 
terioration of functional condition may sometimes be observed by the relapse of a chronic disease, or it may develop during hospital stay even when an impairment is not present in the picture before hospitalization. [2].

When checked the distribution of causes among chronic diseases, rheumatoid diseases make up $64 \%$ of hospitalizations [3]. Such hospital stays are extended due to the facts that diseases are generally of systemic character and require treatment. For instance, patients with systemic lupus erythematosus were reported to have hospital stays extending up to 33 days [4]. In addition to main diseases of patients, diagnostic and therapeutic applications are also carried out for comorbidities. Comorbidity prevalence were reported as $80 \%$ for patients with rheumatoid arthritis [5].

In literature, most of the studies that focus on functional losses observed during hospitalization were conducted on elderly population and post-operative patients $[1,2,6,-8]$. In the said studies, functional conditions were examined by more global scales instead of questionnaires investigating the affected part of the body $[1,7,8]$. However, the structure of body that is used in the most effective manner during daily life activities is hands. The functional condition of the hand affects various daily life activities ranging from self-care to mobility. Any injuries of the hand causes losses in functionality [9]. It was demonstrated that limitations in hand negatively affect participation and independency in small joint osteoarthritis in hands and kidney disease patients undergoing haemodialysis $[10,11]$.

Despite the presence of numerous methods that evaluate the functional conditions of hospitalized patients, grip strength is the most practical among such methods. This method also allows for comparisons in different populations. In a systematic compilation analyzing the results of a total of forty five studies, poor grip strength was concluded as the most consistent predictor for hospital stay and mortality in varying populations [12]. Although these studies tackled the relation between hospitalization and grip strength, studies evaluation the functional condition of the hand in detail are quite insufficient. In addition, population on which these studies focus are generally elderly people $[1,2,8,13]$.

The aim of this study is to investigate how the hand functions of patients with RA are affected in a hospital environment where the daily life is maintained. To this end, hand functions of hospitalized patients with RA and patients with RA followed up as outpatients belonging to the same age group were compared, and the effects of hospitalization were thus tried to be established.

\section{METHODS}

This study included two groups of patients, one being the inpatients at the Rheumatology Department of the Faculty of Medicine of Gazi University and the other being outpatients regularly followed up at the outpatient clinic. From the participants included in the study, informed consents were obtained following a detailed briefing. Patient anonymity is carefully preserved by the researchers.

\section{Patients}

Inpatients were included in the evaluation on day 7 of their admission, and outpatients were included on their routine check-up days. Inclusion criteria were being above the age of 18, diagnosis of RA by a rheumatology specialist, absence of any congenital deformity in upper extremities or no injuries or disorders like neuropathies in the last 6 months or a history of surgery, and being literate. Patients with cognitive disorders and medical conditions of which were not suitable for evaluation were excluded from the study. Additional criteria were established as having no changes in medical treatment and no inflammation in the last month for outpatients, and having no biological agent or high dose steroid treatment commenced since hospitalization or without any increase in steroid dosage already being used for inpatients. Patients hospitalized in the previous 3 months were excluded from the study.

Age, gender, dominant side, deformities in the hands, group the patients belong, and their latest tested erythrocyte sedimentation rates (ESR), and C-reactive protein (CRP) levels of patients were recorded. A scoring system developed for RA, Disease Activity Score-28 (DAS28) was used to establish the disease activity level [14].

\section{Functional Tests}

Functional condition of the hand was evaluated by grip strength and pinch strength measurements, 9-hole Peg Test (9HPT), and the Turkish version of Michigan Hand Outcomes Questionnaire (MHOQ) [15].

Grip strength and pinch strength measurements were carried out while the patient was in a sitting position on a chair with back support, shoulder being in adduction, elbow in $90^{\circ}$ flexion and 
forearm in neutral position based on the standard protocol established by the American Society of Hand Therapists (16). The entire measurements were conducted by the same researcher for both hands and repeated three times, and mean values were recorded in kilogram-force (kg-f). Pinch strength measurement was conducted by a pinchmeter as lateral, bipod, and tripod grips, and gross grip strength measurement was carried out by using a dynamometer.

A speed test that evaluates the functional condition of the hand, 9HPT is based on the performance in which nine pegs are placed in and then removed from a block with nine holes. It is a valid, reliable and objective test allowing to evaluate the hand functions in a practical manner in various populations [17].

$\mathrm{MHOQ}$ is filled by the patient regarding the issues with hands. It provides the evaluation of functional condition of the hand, satisfaction from the condition of the hand, and pain from the viewpoint of patient, thus establishing the level of disability [15].

\section{Statistical Analysis}

Result measurements of the patient groups were provided as mean \pm standard deviation. Since it was established that values did not comply with normal distribution in both groups, nonparametric tests were utilized. Age, ESR, CRP levels and functional test scores of the two groups were numerical values and were compared with Mann-Whitney $U$ test. For statistical significance $p<0.05$ was accepted.

\section{RESULTS}

The study included 29 inpatients from the clinic and 21 outpatients. Of the inpatients, 26 were female and 3 male; and 15 of the outpatients were female and 6 were male. Mean ages of inpatients that were $49 \pm 15$ and outpatients that were $45 \pm 9$ were similar $(p=0.191)$. None of the patients had hand deformities. ESR $(p=0.01)$ and CRP $(p=0.034)$ levels of inpatients were found as higher compared to the outpatient group. When checked the DAS28 scores of patients, the mean score of inpatient group was $2.9 \pm 0.4$; and the mean score of outpatient group was established as $2.7 \pm 0.1$. Both patient groups whose DAS28 results were comparable $(p>0.05)$ were concluded to fall in low disease activity category (DAS28 2.6-3.2).

When compared the grip and pinch strengths of the groups, it was observed that gross grip strengths of right and left hands were alike $(p>0.05)$. Furthermore, lateral, bipod, and tripod pinch strengths were found as higher in outpatient group for both right hand $(p=0.008 ; p=0.009 ; p=0.006$, respectively) and left hand $(p=0.007 ; p=0.001 ; p=0.006$, respectively) (Table 1).

Table 1. Grip and all three pinching strength results of inpatient and outpatient groups

\begin{tabular}{|c|c|c|c|c|}
\hline & & Outpatients & Inpatients & $\mathbf{p}$ \\
\hline \multirow[t]{2}{*}{ Grip strength $(\mathrm{kg})$} & $\mathrm{R}$ & $4 \pm 1$ & $4 \pm 2$ & 0.419 \\
\hline & $\mathrm{L}$ & $4 \pm 1$ & $3 \pm 2$ & 0.059 \\
\hline \multirow[t]{2}{*}{ Lateral pinch $(\mathrm{kg})$} & $\mathrm{R}$ & $8 \pm 2$ & $6 \pm 2$ & 0.008 \\
\hline & $\mathrm{L}$ & $7 \pm 2$ & $5 \pm 3$ & 0.007 \\
\hline \multirow[t]{2}{*}{ Bipod pinch (kg) } & $\mathrm{R}$ & $5 \pm 1$ & $4 \pm 1$ & 0.009 \\
\hline & $\mathrm{L}$ & $5 \pm 1$ & $3 \pm 2$ & 0.001 \\
\hline \multirow[t]{2}{*}{ Tripod pinch (kg) } & $\mathrm{R}$ & $7 \pm 1$ & $5 \pm 2$ & 0.006 \\
\hline & $\mathrm{L}$ & $6 \pm 1$ & $4 \pm 3$ & 0.006 \\
\hline
\end{tabular}

When compared the 9HPT results of both groups, both placement $(p<0.001)$ and removal $(p=0.004)$ times of the right hand and placement time $(p=0.009)$ of the left hand in inpatient group were found as longer. Although the removal time of left hand was longer in inpatient group, the difference was not statistically significant $(p=0.057)$ (Table 2).

Table 2. Replacement and removal time of Nine-Hole Peg Test of both hands in outpatient and inpatient groups

\begin{tabular}{lccc}
\hline & Outpatients & Inpatients & $\mathbf{p}$ \\
\hline Right replacement (sec) & $12 \pm 1$ & $15 \pm 3$ & $<0.001$ \\
Left replacement (sec) & $13 \pm 1$ & $16 \pm 4$ & 0.004 \\
Right removal (sec) & $5 \pm 1$ & $7 \pm 1$ & 0.009 \\
Left removal (sec) & $6 \pm 1$ & $7 \pm 1$ & 0.057 \\
\hline
\end{tabular}

As a result of the comparison of $\mathrm{MHOQ}$ scores, mean score of inpatient group was found as 51.76; and mean score of outpatient group was established as 64.89. Even though the score of inpatient group was lower, the said difference was not statistically significant $(p=0.064)$.

\section{DISCUSSION}

This study established that fine grip of patients with RA and their hand functions requiring swiftness were weaker compared to outpatients. In addition, disability level of the hand was higher in inpatients despite it not having reached a statistical difference. 
Gross grip strengths of both groups were found as similar. Our study is the first of its kind in that it evaluates hand functions in detail and includes a certain patient group at middle age compared to other studies in literature measuring only the gross grip strength. Almost all previous studies were carried out by including elderly or much older populations. The global effect of hospitalization to functional condition was investigated only by various scales such as Barthel Index or Functional Independence Measure [18-21]. In addition to this, occupational therapy was found to be necessary for patients with chronic conditions in a previous study, however, the assessment of additional effects of hospitalization on those patients lacks [22]. For those reasons, our study differs from other available studies in terms of the age group, patient population, and evaluation methods.

The fact that gross grip strength results of groups were found as similar and pinch strengths were established as weaker in inpatients in our study demonstrates that hospitalization affects the fine grip skill of the hand more. Literature shows that gross grip is the most powerful indicator for functional deterioration and disability [23]. Gross grip strength measured in hospitalized patients was also shown to have a correlation with hospital stay and re-hospitalization possibility [20,24]. In all these said studies, whether there is a statistical correlation between gross grip strength and hospital stays were analyzed and a multitude of participants were included $[20,25]$. Unlike these studies, our study compared the results of inpatients hospitalized the first time and of outpatients. It is also observed in literature that fine grip and speed-based hand function were not evaluated. However, gross grip is more of a function that involves extrinsic muscles of the hand. Hand functions that require fine skills are manifested more by the participation of intrinsic muscles of the hand. Intrinsic muscles are located around the small joints of the hand and thus are more affected from chronic inflammatory process and get weaker more. As also noted in previous studies, intrinsic muscle weakness may be observed depending only on inflammation and disuse without the presence of a deformity in the hand [26]. In this case, any sort of grip strength is affected from severe intrinsic weakness. In our patients, too, fine grips were found as lower despite the absence of a deformity in the hand. This condition is believed to stem from intrinsic muscle weakness caused by chronic inflammation and from insufficient participation to function.
The fact that ESR ad CRP levels that show disease activity were found as higher in the inpatient group was an expected outcome. In addition, fine grip strength measurement and speed-based functional results of inpatients were established as worse. When these results are interpreted in conjunction, high disease activity may be considered to have affected hand functions, however, the fact that gross grip strength was similar in both groups demonstrate that chronic inflammation has a higher influence intrinsic muscles. Also, even though ESR and CRP levels of inpatients were higher, disease activities of both groups were observed as similar according to DAS-28. ESR and CRP levels take a significant place for tracking the disease activity. However, these two indicators may rise other inflammatory foci in addition to rheumatoid diseases. Yet, DAS-28 is an RA-specific scale and evaluates laboratory findings together with clinical symptoms. The fact that disease activity was found as similar based on our results demonstrates that both groups possessed comparable clinical picture. Furthermore, gross grip function is accompanied by more small joints compared to other grip types. Therefore, its likelihood of being affected from disease activity is naturally higher. However, that gross grip strength was found as similar and pinch strength was established as different based on our results give rise to the thought of disease activity making intrinsic muscles much weaker.

Lack of psychological condition evaluation may be noted as the shortcoming of our study since functionality is a result that is not only affected by body systems but also by personal and environmental factors [10]. In addition, the fact that a difference was found in fine grips despite our low number of participants shows that these functions were quite affected. On the other hand, such differences not reaching statistical difference in inpatients with weaker gross grip and higher disability level may stem from the insufficient number of participants.

Consequently, hospitalization has an impact on functional use of the hand especially in activities requiring fine grip. Higher disease activities of hospitalized patients also cause fine grips to be affected more. Inclusion especially of hand rehabilitation practices concerning fine grips during hospitalization to routine treatment would be effective in preventing hand dysfunction that is among numerous physical side effects accompanied by the hospitalization process. 


\section{REFERENCES}

1. Carmen G, Luis CG, Luis MG, et al. Handgrip Strength Predicts Functional Decline at Discharge in Hospitalized Male Elderly: A Hospital Cohort Study. PLoS ONE 2013; e69849.

2. Fortinsky RH, Covinsky HE, Palmer RM, Landefeld CS. Effects of functional status changes before and during hospitalization on nursing horne admission of older adults. J Gerontol Med Sci 1999;54:521-526.

3. Hood C, Johnson J, Kelly C. What is the prevalence of rheumatic disorders in general medical inpatients? Postgrad Med J 2001;77:774-777.

4. Krishnan E. Hospitalization and mortality of patients with systemic lupus erythematosus. J Rheumatol 2006;33:1770-1774.

5. Parodi M, Bensi L, Maio T, et al. Comorbidities in rheumatoid arthritis: analysis of hospital discharge records. Reumatismo 2005;57:154-160.

6. Davydow DS, Hough CL, Levine DA, et al. Functional disability, cognitive impairment, and depression after hospitalization for pneumonia. Am J Med 2013;126:615-624.

7. Guy N, Justo D, Lerman Y, Rabinovich A. Length and outcome of acute inpatient rehabilitation for hospitalassociated deconditioning in the elderly]. Harefuah 2012;151:500-504.

8. Kerr A, Syddall HE, Cooper C, et al. Does admission grip strength predict length of stay in hospitalised older patients? Age Ageing 2006;35:82-84.

9. Kus S, van de Ven-Stevens LA, Coenen M, et al. What is our knowledge of functioning and disability in hand conditions based on? Arch Phys Med Rehabil 2011;92:1326-1332.

10. Kjeken I, Dagfinrud H, Slatkowsky-Christensen B, et al. Activity limitations and participation restrictions in women with hand osteoarthritis: patients' descriptions and associations between dimensions of functioning. Ann Rheum Dis 2005;64:1633-1638.

11. Tuna Z, Oskay D, Önder D, İnal S. Assessment of hand dysfunction in patients receiving hemodialysis through arteriovenous fistula. J Clin Exp Invest 2015;6:110-114.

12. Bohannon RW. Hand-grip dynamometry predicts future outcomes in aging adults. J Geriatr Phys Ther 2008;31:3-10.

13. Keevil V, Mazzuin RR, Chin AV, et al. Grip strength in a cohort of older medical inpatients in Malaysia: a pilot study to describe the range, determinants and association with length of hospital stay. Arch Gerontol Geriatr 2013;56:155-159.

14. Pinals RS, Masi AT, Larsen RA. Preliminary criteria for clinical remission in rheumatoid arthritis. Arthritis Rheum 1981;24:1308-1315.

15. Öksüz Ç, Akel BS, Oskay D, et al. Cross-cultural adaptation, validation, and reliability process of the Michigan Hand Outcomes Questionnaire in a Turkish population. J Hand Surg Am 2011;36:486-492.

16. Mathiowetz V, Weber K, Volland G, Kashman N. Reliability and validity of grip and pinch strength evaluations. J Hand Surg Am 1984;9:222-226.

17. Smith YA, Hong E, Presson C. Normative and validation studies of the Nine-hole Peg Test with children. Percept Mot Skills 2000;90:823-843.

18. Zisberg A, Zlotnick C, Gur - Yaish N, et al. Functional decline and satisfaction with nursing care among older hospitalized adults. Int J Nursing Practice 2014 doi: 10.1111/ijn.12289.

19. Morandi A, Bellelli G, Vasilevskis EE, et al. Predictors of rehospitalization among elderly patients admitted to a rehabilitation hospital: the role of polypharmacy, functional status, and length of stay. J Am Med Directors Assoc 2013;14:761-767.

20. Hoyer EH, Needham DM, Atanelov L, et al. Association of impaired functional status at hospital discharge and subsequent rehospitalization. J Hosp Med 2014;9:277-282.

21. Shearer T, Guthrie S. Facilitating early activities of daily living retraining prevent functional decline in older adults . Aust Occup Ther J 2013;60:319-325.

22. O'Toole L, ConnollyD, Smith S. Impact of an occupation-based self-management programme on chronic disease management Aust Occup Ther J 2013;60:3038.

23. Hoogerduijn JG, Buurman BM, Korevaar JC, et al. The prediction of functional decline in older hospitalised patients. Age Ageing 2012;41:381-387.

24. Legrand D, Vaes B, Matheï C, et al. Muscle strength and physical performance as predictors of mortality, hospitalization, and disability in the oldest old. J Am Geriatr Soc. 2014;62:1030-1038.

25. Palleschi L, Fimognari FL, Pierantozzi A, et al. Acute functional decline before hospitalization in older patients. Geriatr Gerontol Int 2014;14:769-777.

26. Towheed TE, Anastassiades TP. Rheumatoid hand. Practical approach to assessment and management. Can Fam Physician 1994;40:1303-1309. 